\title{
Pain and musculoskeletal discomfort in military police officers of the Ostensive Motorcycle Patrol Group
}

\author{
Dor e desconforto musculoesquelético em policiais militares do Grupamento de Rondas \\ Ostensivas com Apoio de Motocicletas
}

Katianna Karolinna Fernandes Maia Braga', Francis Trombini-Souza1, Michele Vantini Checchio Skrapec ${ }^{1}$, Diego Barbosa de Queiroz $^{1}$, Andréa Marques Sotero ${ }^{1}$, Tarcísio Fulgêncio Alves da Silva ${ }^{1}$

DOI 10.5935/2595-0118.20180007

\section{ABSTRACT}

BACKGROUND AND OBJECTIVES: Work-related musculoskeletal disorders have shown a high prevalence among workers, among these, law enforcement officers have been greatly affected. The aim of this study was to analyze the occurrence of musculoskeletal disorders symptoms in the Ostensive Motorcycle Patrol Group of the Military Police of Pernambuco, PE.

METHODS: This was a cross-sectional study developed from February to June 2016. The subjects were 28 police officers from the Ostensive Motorcycle Patrol Group, of the $5^{\text {th }}$ Battalion of the Military Police. Data was collected through a self-administered questionnaire with sociodemographic variables and professional characteristics. The Nordic Musculoskeletal Questionnaire and the visual analog scale were used.

RESULTS: In the study sample, most of the individuals were male with an average of $62 \pm 8$ working hours per week. Regarding the presence of musculoskeletal symptoms, the most affected anatomical region was the back, followed by the knees and then the chest. As for the pain perception of the subjects, the spine and lower limbs showed higher pain intensity when compared to other regions. Most of the sample believe that musculoskeletal symptoms are related to work.

CONCLUSION: The findings in this study demonstrate the presence of musculoskeletal symptoms in the studied population. The analysis of the musculoskeletal disorders of these police officers will serve as an input for the planning of intervention actions to improve the general conditions of the service provided by the Ostensive Motorcycle Patrol Group.

Keywords: Chronic pain, Military personnel, Motorcycles, Musculoskeletal pain, Police.

1. Universidade de Pernambuco, Petrolina, PE, Brasil.

Submitted in July 07, 2017.

Accepted for publication in January 21, 2018.

Conflict of interests: none - Sponsoring sources: none

Correspondence to

Rodovia BR 203, Km 2, s/n - Vila Eduardo

56328-903 Petrolina, PE, Brasil.

E-mail: tarcisio.silva@upe.br

(๑) Sociedade Brasileira para o Estudo da Dor

\section{RESUMO}

JUSTIFICATIVA E OBJETIVOS: Os distúrbios osteomusculares relacionados ao trabalho têm apresentado alta prevalência nos trabalhadores, dentre esses, a classe de policiais tem sido bastante acometida. O objetivo deste estudo foi analisar a ocorrência de sintomas de distúrbios osteomusculares em policiais do Grupamento de Rondas Ostensivas Com Apoio de Motocicletas da Polícia Militar de Pernambuco, PE.

MÉTODOS: Trata-se de um estudo do tipo transversal, desenvolvido entre os meses de fevereiro a junho de 2016, com 28 indivíduos da Rondas Ostensivas Com Apoio de Motocicletas da Polícia Militar do $5^{\circ}$ Batalháo de Polícia Militar. Os dados foram obtidos por meio de um questionário autoaplicável com variáveis sociodemográficas, características profissionais, Questionário Nórdico de Sintomas Osteomusculares e escala analógica visual. RESULTADOS: Dentre a amostra estudada, a maioria dos indivíduos era do sexo masculino, sendo observada uma média de $62 \pm 8$ horas trabalhadas por semana. Em relação à presença de sintomas osteomusculares, a regiáo anatômica mais acometida foi a lombar, seguida pelos joelhos e regiāo torácica. Quanto à percepção de dor dos policiais, a coluna vertebral e os membros inferiores apresentaram maior intensidade de dor quando comparados às outras regióes avaliadas. A maioria dos indivíduos da amostra relatou que os sintomas osteomusculares estavam relacionados ao trabalho.

CONCLUSÁO: Os resultados deste estudo demonstram a presença de sintomas osteomusculares na população estudada de forma unânime. A análise dos distúrbios osteomusculares desses policiais servirá como subsídio para o planejamento de açōes de intervençáo voltados para a melhoria das condiçóes gerais de prestação de serviços da Rondas Ostensivas Com Apoio de Motocicletas.

Descritores: Dor crônica, Dor musculoesquelética, Militares, Motocicletas, Polícia.

\section{INTRODUCTION}

Work-related musculoskeletal disorders (WRMD) are common in several professions and result in a high proportion of injuries. Among the risk factors for WRMD are the repetitive, forceful or uncomfortable movements, as well as continuous pressure, excessive use of specific anatomical structures or region, posture alteration or inadequate positioning, excessive force, tension extreme and vibrations imposed to the body ${ }^{1}$. 
Of the several classes of workers, we can highlight those responsible for the preservation of the public order: the police officers. These professionals can constantly be exposed to countless risk factors to development WRMD. A recent Canadian study where 3,589 vehicle patrolling police officers were evaluated using an online questionnaire, showed that $67.7 \%$ reported chronic low back pain (CLBP) and 96.5\% noticed that the CLBP presence was partially related to their work in the Canadian police corporation ${ }^{2}$.

In Brazil, motorcycles are another patrolling modality. The Ostensive Motorcycle Patrol Group (ROCAM, in Portuguese) of the Military Police of Pernambuco (MPPE) was created an innovative patrolling model specifically to combat crimes by criminals using motorcycles ${ }^{3}$.

Among the activities performed by ROCAM police officers, we can list get on and off the bike in due course, approach suspects while riding, dangerous overtaking and maneuvers, attention to the traffic and the patrol team, considering that the operational job must be carried by, at least, two policemen on each patrol ${ }^{3}$. The physical and mental stress inherent to this work activity, the weight of the weapons, the uniform and the equipment, as well as the overload on the spine, upper and lower limbs and the emotional stress due to the patrol riding and the heat of the bike engine can be responsible for the high levels of absenteeism of these workers ${ }^{4,5}$.

All these mechanical aspects of the motorcycle and the roads, as well as the emotional and biomechanical aspects on these motorcycle professionals, can contribute to the increasing world public health problem in this segment of military workers.

However, in Brazil, especially related to the important and indispensable work of the ROCAM officers, there is not yet an epidemiological panorama about WRMD. Moreover, there are no studies that evidence if this type of work activity, in fact, can influence the pain perception and body discomfort suffered by these police officers.

In case this is confirmed by the present study, some determinants for disability and absenteeism of these workers ${ }^{6-8}$ can be better approached to minimize the subsequent damages from the imposed extreme use to the musculoskeletal system, mainly when associated to the lack of time for recovery after long hours of work on motorcycles. In a complementary form, with the results of this study, it will be possible to publish scientific information that can serve as input for an interventional action plan to improve the general conditions of the services provided by ROCAM.

The hypothesis was: (i) the type of work activity performed by ROCAM police officers could evidence the higher prevalence of pain and body discomfort, mainly, in the low back region (lumbar region) and wrist/hands; (ii) the working period of the ROCAM police officers could be associated with higher prevalence of pain and discomfort in the above-mentioned regions.

The objective of this study was to analyze the occurrence of WRMD symptoms in the ROCAM police officers of the MPPE in Petrolina.

\section{METHODS}

This is a cross-sectional study conducted from February to June 2016 at the Polyclinic of the MPPE. According to the sample size calculation done by the GPower 3.0 software, in which it was adopted an $\mathrm{X}$ statistics of ${ }^{2}$, with effect size of $\mathrm{W}=0.8, \alpha=0.05$, test power $\beta=0.90$ and a population of 33 members that compose the ROCAM of the $5^{\text {th }}$ Battalion of the Military Police (BMP), we came up with a sample of 26 police officers necessary for the conclusions of the present study. However, when considering a possible sample loss of $5 \%$, it was necessary to evaluate 28 police officers, and the single eligibility criterion was to be in the motorcycle patrolling function for at least 12 months.

Data collection was conducted in accordance with the work schedule of the police officers at the beginning of the shift, which was previously authorized by ROCAM chief officer, with no harm to the course of the work.

The data was obtained after consent, by means of a selfapplicable questionnaire including the following variables: sociodemographic characteristics (gender, marital status, age and education); professional characteristics (tenure, time with ROCAM, hours worked per week and overtime); other information (performance of physical exercises and diagnosis of any disease in the last 12 months). The Nordic Musculoskeletal Questionnaire (NMQ) was used. This tool was validated and adapted for the Brazilian population by Pinheiro, Troccoli, and Carvalho', containing multiple choices for musculoskeletal symptoms in several anatomic regions as well as the visual analog scale (VAS) that assesses the perception of pain intensity. The final pain score, varying from zero to 10 , where zero means the absence of pain and 10 the worse pain possible, was categorized according to Boonstra et al. ${ }^{10}$ as mild (scores $\leq 5$ ), moderate (scores 6 or 7) and severe (scores $\geq 8$ ).

Five of the 33 ROCAM police officers were not included in the present study because they were in the motorcycle patrol activity for less than one year.

This project was approved by the Research Ethics Committee of the University of Pernambuco (UPE), according to Resolution number 466, of December 12, 2012, of the National Health Council/Department of Health (CAAE: 53811816.5.0000.5207).

\section{Statistical analysis}

It was used the Statistical Package for Social Sciences software (SPSS), version 22.0.

\section{RESULTS}

The studied sample was composed of 28 ROCAM police officers of the $5^{\text {th }}$ BPM, with age of $34 \pm 5$ years, varying between 24 and 48 years, with a predominance of males, $82.1 \%$ married. In the studied sample, the majority reported being working at MPPE for less than 10 years and as a motorcycle patrol officer at ROCAM for less than 5 years. As for the 
working time, it was observed an average of $62 \pm 8 \mathrm{~h}$ per week, of which $14.28 \%$ of the sample reported no overtime in other activities of the PMPE. When questioned about the practice of physical exercises, the majority told to do it three times per week with minimum duration of 30 minutes, including bodybuilding, jogging, and martial arts (Table 1).

Table 1. Characterization of the sample, according to sociodemographic variables, professional characteristics, and practice of physical exercise. Petrolina, PE, 2016

\begin{tabular}{lcc}
\hline Variables & $\mathrm{n}$ & $\%$ \\
\hline Gender & & \\
$\quad$ Female & 01 & 3,6 \\
$\quad$ Male & 27 & 96,4 \\
Marital status & & \\
$\quad$ Single & 04 & 14,3 \\
$\quad$ Married & 23 & 82,1 \\
$\quad$ Divorced & 01 & 3,6 \\
Job tenure at MPPE (years) & & \\
$\quad<10$ & 22 & 78,6 \\
$>10$ & 06 & 21,4 \\
Job tenure at ROCAM (years) & & \\
$\quad<5$ & 15 & 53,6 \\
$>5$ & 13 & 46,4 \\
Physical exercise & & \\
Yes & 19 & 67,8 \\
$\quad$ No & 09 & 32,2 \\
\hline MPPE = Military Police of Pernambuco.
\end{tabular}

Figure 1 shows that the anatomical region most involved by pain and discomfort in the studied sample was the lower back with a prevalence of $50 \%$, followed by the knees with $43 \%$. The less involved body segments were the shoulder (7\%) and wrist/hand $(7 \%)$.

According to the intensity of musculoskeletal symptoms reported by the ROCAM police officers, in accordance with the VAS, we identified that the anatomical regions with higher intensity of severe pain were the spine and the lower limbs (Table 2).
Table 2. Frequency of intensity of musculoskeletal symptoms reported by the ROCAM police officers, according to the analog visual scale

\begin{tabular}{lccc}
\hline Anatomical regions & Mild & Moderate & Severe \\
\hline Spine (19) & 0 & $84.2 \%$ & $15.8 \%$ \\
UL (04) & 0 & $100 \%$ & 0 \\
LL (16) & 0 & $81.2 \%$ & $18.8 \%$ \\
\hline
\end{tabular}

$\mathrm{UL}=$ upper limbs; $\mathrm{LL}=$ lower limbs.

As for the characterization of pain, according to the "almost always" and "always" frequency, $46.4 \%$ reported pain when working as shown in table 3 . When questioned if the symptoms worsened when working, $28.6 \%$ of the subjects had musculoskeletal symptoms.

Table 3. Characterization of the pain, according to the frequency

\begin{tabular}{lcc}
\hline Pain frequency & Comes before work & Comes during work \\
\hline Never & $10.7 \%$ & 0 \\
Almost never & $14.3 \%$ & $3.6 \%$ \\
Sometimes & $53.6 \%$ & $50 \%$ \\
Almost always & $14.3 \%$ & $21.4 \%$ \\
Always & $7.1 \%$ & $25 \%$ \\
Total & $100 \%$ & $100 \%$ \\
\hline
\end{tabular}

\section{DISCUSSION}

It was observed that most subjects were predominantly male. According to Capelle ${ }^{11}$, the Military Police is considered an organization of masculine character, where it is necessary to act with energy in situations of urban violence, conveying a representation market by aggressiveness. Ferreira, Bonfim, and Augusto ${ }^{12}$ affirmed in their study with police officers in Pernambuco, that this is a predominantly masculine environment, with a recent and gradual presence of females in the military career.

With respect to job tenure, most of the interviewed subjects indicate a relatively recent staff, less than 10 years in the corpora-

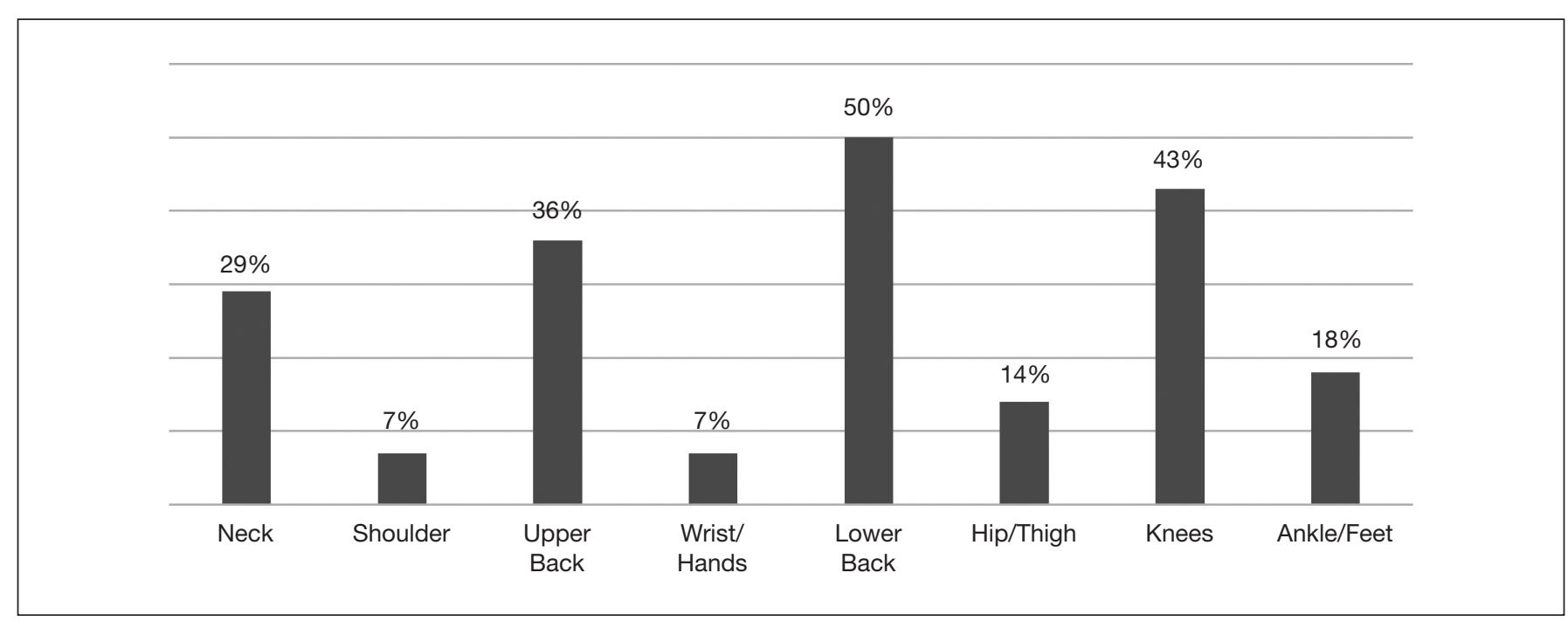

Figure 1. Prevalence of the anatomical regions most involved in pain and discomfort 
tion, which corresponds to about one-third of the total time in the military career, reflecting a policy of maintenance and substitution of the operational staff of the military organization ${ }^{5}$. In relation to the hours of work, it was observed an average of 62 hours per week, including weekly work hours and overtime. According to Minayo, Assis, and Oliveira ${ }^{5}$, the workload of these professionals is enlarged since they work on their day off as a way to complement their income.

In the police activity, specifically, it is essential the practice of physical exercises, since due to their function, it is necessary to have good physical performance in order to ensure the public $\operatorname{order}^{4,5}$. Among the studied police officers, the majority reported the practice of physical exercises. However, an important percentage said not having any physical activity at all, which can harm the professional performance, since a sedentary person has a less physical capacity to do functional movements in their Daily Life Activities (DLA) and work activities, being exposed to musculoskeletal symptoms ${ }^{13,14}$.

Among the regions involved, the lower back was predominant in terms of more pain complaint among the police officers interviewed. Oliver and Middledith ${ }^{15}$ presented some effects on the lumbosacral curve and found that when sitting at $90^{\circ}$, there is the rectification of the lumbar curve. These results corroborate the study by Marques, Hallal, and Gonçalves ${ }^{16}$. This might have happened with the studied population, since during the work hours the ROCAM police officers remain sitting for 16 to 18 hours at $90^{\circ}$ of hip and knees, adding the additional load of the equipment, weapons and the uniform, as well as the impact of the motorcycle when riding over obstacles on highways, alleys, and streets. Minayo, Assis, and Oliveira ${ }^{5}$ in, their study with military and civil policemen, observed that back pain is among the most frequent musculoskeletal injury in this population. Santos et al. ${ }^{17}$, Gonçalves, Trombetta and Gessinger ${ }^{18}$, reported the prevalence of musculoskeletal disorders in the spine of motorcycle taxi drivers, which corroborates the results of this study. Oliveira and Santos ${ }^{19}$, when studying police officers, noticed that most of the studied population, always or sometimes, felt physically and emotionally tired after the work day. In this study, we t can observe that musculoskeletal symptoms were common, always or sometimes when working and that they worsened with the execution of movements. Low back pain in police officers is frequent due to the overload on the musculoskeletal system, sometimes requiring the use of the force and agility during the situations inherent to the profession ${ }^{13}$.

It was also observed that the majority of the ROCAM police officers believe that the musculoskeletal symptoms are related to the work activities. It is worth mentioning that the physical trauma experienced by police officers are closely linked to the professional activity ${ }^{8,19}$ which requires them to run, approach, jump, ride, requiring a major physical demand and a good fitness level ${ }^{20}$. According to Tavares Neto et al. ${ }^{13}$, the work activity of police officers tends naturally to complaints of low back pain.
The relatively small sample poses some limitations to this study imply that can be justified by the small staff of the $5^{\text {th }}$ BMP ROCAM. Since it is a descriptive study, it was not possible to make a correlation with posture assessment, requiring new studies on the subject. With the data obtained, we can identify musculoskeletal symptoms in the police officers of ROCAM.

\section{CONCLUSION}

The results of this study corroborate the notorious presence of musculoskeletal symptoms in the studied population, where the lumbar spine was the region with the highest number of pain complaints that aggravated when working, suggesting possible work-related musculoskeletal disorders.

\section{REFERENCES}

1. Melhorn JM. Cumulative trauma disorders and repetitive strain injuries. The future Clin Orthop Relat Res. 1998;(351):107-26.

2. Benyamina Douma N, Côte C, Lacasse A. Quebec serve and protect low back pain study: a web-based cross-sectional investigation of prevalence and functional impact among police officers. Spine. 2017;42(19):1485-93.

3. Brasil, 2010. Ministério da Justiça. Secretaria Nacional de Segurança de Pública. Departamento Nacional de Policiamento com motocicletas. 2010; Belém-PA, maio.

4. Costa M, Júnior HA, Oliveira J, Maia E. [Stress: diagnosis of military police personnel in a Brazilian city]. Rev Panam Salud Publica. 2007;21(4):217-22. Portuguese.

5. Minayo MC, Assis SG, Oliveira RV. Impacto das atividades profissionais na saúde física e mental dos policiais civis e militares do Rio de Janeiro (RJ, Brasil). Ciênc Saúde Coletiva. 2011;16(4):2199-209.

6. Trindade LL, Schuh MC, Krein C, Ferraz L, Amestoy SC. Dores osteomusculares em trabalhadores da indústria têxtil e sua relação com o turno de trabalho. Rev Enferm UFSM. 2012;2(1):108-15.

7. Vitta A, Canonici AA, Conti $\mathrm{MH}$, Simeão SF. Prevalência e fatores associados à dor musculoesquelética em profissionais de atividades sedentárias. Fisioter Mov. 2012;25(2):273-80

8. Lima Júnior JP, Silva TF. Análise da sintomatologia de distúrbios osteomusculares em docentes da Universidade de Pernambuco - Campus Petrolina. Rev Dor. 2014; 15(4):276-80

9. Pinheiro FA, Troccoli BT, Carvalho CV. [Validity of the Nordic Musculoskeletal Questionnaire as morbidity measurement tool]. Rev Saude Publica. 2002;36(3):30712. Portuguese.

10. Boonstra AM, Stewart RE, Köke AJ, Oosterwijk RF, Swaan JL, Schreurs KM, et al Cut-off points for mild, moderate, and severe pain on the numeric rating scale for pain in patients with chronic musculoskeletal pain: variability and influence of sex and catastrophizing. Front Psychol. 2016;7(1466):1-9.

11. Capelle MC. Mulheres policiais, relação de poder e de sexo na Polícia Militar de Minas Gerais. Rev Adm Mackenzie. 2010;11(3):71-99.

12. Ferreira DK, Bonfim C, Augusto LG. Condiçốes de trabalho e morbidade referida de policiais militares, Recife-PE, Brasil. Saúde Soc. 2012;21(4):989-1000.

13. Tavares Neto A, Faleiro TB, Moreira FD, Jambeiro JS, Schulz RS. Lombalgia na atividade policial militar: análise da prevalência, repercussốes laborativas e custo indireto. Rev Baiana de Saúde Pública. 2013;37(2):365-74.

14. Calasans DA, Borin G, Peixoto GT. Lesóes musculoesqueléticas em policiais militares. Rev Bras Med Esporte. 2013;19(6):415-8.

15. Oliver J, Middledith A. Anatomia funcional da coluna vertebral. Rio de Janeiro: Revinter; 1998.

16. Marques NR, Hallal CZ, Gonçalves M. Características biomecânicas, ergonômicas e clínicas da postura sentada: uma revisão. Fisioter Pesq. 2010;17(3):370-6.

17. Santos LB, Amorim CR, Vilela AB, Rocha SV, Cardoso JP. Prevalência de sintomas osteomusculares e fatores associados entre mototaxistas de um município brasileiro. Rev Baiana de Saúde Pública. 2014;38(2):417-31.

18. Gonçalves EC, Trombetta JB, Gessinger CF. Prevalência de dor na coluna vertebral em motoboys de uma cooperativa de Porto Alegre, RS. Rev AMRIGS. 2012;56(4):314-9.

19. Oliveira KL, Santos LM. Percepção da saúde mental em policiais militares de força tática e de rua. Sociologias. 2010;12(25):224-50.

20. Jesus GM, Jesus EF. Nível de atividade física e barreiras percebidas para a prática de atividades físicas entre policiais militares. Rev Bras Cienc. 2012;34(2):433-48. 